\title{
ANALISIS EFEKTIFITAS PEMBELAJARAN DARING BERBASIS WEBSITE \\ (STUDI KASUS SISWA KELAS X AKUNTANSI LEMBAGA DI SMKN 2 SITUBONDO MATA PELAJARAN SIMULASI DIGITAL)
}

\author{
Ro'is Akbari', Siti Seituni ${ }^{2}$ \\ ${ }^{1,2}$ STKIP PGRI Situbondo, Indonesia \\ e-mail: acikspdi82@gmail.com
}

\begin{abstract}
E-learning innovation is a new learning model in education which provides a big role and function for the world of education. This is to answer the shortcomings and weaknesses of conventional education (education in general) including the limitations of space and time in the conventional education process. Therefore this research was carried out with the aim of analyzing and describing the effectiveness of online learning based on the website. Case Study of Class X Akl 1 Students at SMKN 2 Situbondo in Digira Simulation Subject. This research uses a descriptive qualitative approach with the type of case study research with primary and secondary data and data sources. Collecting data using observation, interview and documentation techniques. With the stages of data analysis, namely data reduction, data presentation and then drawing conclusions. The results of data analysis and discussion, in this study, that website-based online learning is effective for students with the conclusion that students can still understand the material easily because the material presented is quite short but clear, the media used is easily accessible for all types of cellphones, website-based online learning It doesn't take a long time, so students have a lot of free time that can be used to help their parents at home, online learning is easy to do anywhere and anytime and online learning based on this website does not make cellphone storage require a lot of space.
\end{abstract}

Keywords: effectiveness analysis, online learning, website-based

Abstrak: Inovasi pembelajaran e-learning merupakan model pembelajaran baru dalam pendidikan dimana memberikan peran dan fungsi yang besar bagi dunia pendidikan. Hal ini untuk menjawab kekurangan dan kelemahan pendidikan konvensional (pendidikan pada umumnya) diantaranya adalah keterbatasan ruang dan waktu dalam proses pendidikan konvensional. Oleh sebab itu penelitian ini dilaksanakan dengan tujuan menganalisis, dan mendeskripsikan Efektifitas Pembelajaran Daring berbasis website Studi Kasus Siswa Kelas X Akl 1 di SMKN 2 Situbondo Mata Pelajaran Simulasi Digira . Penelitian ini menggunakan pendekatan kualitatif Deskriptif dengan jenis penelitian studi kasus dengan data dan sumber data primer dan sekunder. Pengambilan data menggunakan teknik observasi, wawancara dan dokumentasi. Denga tahapan analisis data yaitu reduksi data, penyajian data lalu penarikan kesimpulan. Hasil analisis dan pembahasan data, dalam penelitian ini, bahwa pembelajaran online Berbasis website efektif bagi siswa dengan simpulan Siswa tetap dapat memahami materi dengan mudah karena materi yang disajikan cukup singkat namun jelas, Media yang digunakan mudah diakses bagi semua tipe HP, Pembelajaran online berbasis website tidak membutuhkan waktu yang lama sehingga siswa mempunyai banyak waktu luang yang bisa digunakan untuk membantu orang tuanya di rumah, Pembelajaran online mudah dilakukan dimana saja dan kapan saja dan Pembelajaran online berbasis website ini tidak membuat penyimpanan handphone membutuhkan banyak ruang.

Kata Kunci: analisis efektifitas, pembelajaran daring, berbasis website

Copyright (c) 2021 The Authors. This is an open access article under the CC BY-SA 4.0 license (https://creativecommons.org/licenses/by-sa/4.0/) 


\section{PENDAHULUAN}

Dewasa ini metode belajar pengajar dari tingkat dasar sampai dengan perguruan tinggi sedikit mengalami kebosanan jika hanya menggunakan metode klasik yakni dengan ceramah dan tanya jawab saja. Perlu adanya metode baru untuk meningkatkan semangat belajar mengajar, baik untuk siswa ataupun mahasiswa maupun guru serta dosen.

Pada umumnya, sekolah menerapkan kegiatan pembelajaran tatap muka. hal ini juga berlaku di SMKN 2 SITUBONDO. Namun, sejak adanya pandemi Covid-19. Kemendikbud melalui surat edaran nomor 4 tahun 2020 menganjurkan pelaksanaan kebijakan pendidikan dalam masa darurat penyebaran Covid-19 dilaksanakan di rumah melalui pembelajaran secara online ataupun daring.

Peran pendidikan pada saat ini diharapkan terus menerus menciptakan inovasi demi keberlangsungan pembelajaran pada peserta didik, sejak diberlakukannya pembelajaran Daring, maka pendidik berperan untuk mengubah metode pembelajaran dari tatap muka menjadi sistem online yang telah berhasil pada perkembangan, Hasil pengembangan produk media pembelajaran berbasis web mata mata pelajaran IPA bagi siswa kelas VII SMP se Kecamatan Depok Sleman berhasil dikembangkan menggunakan CMS (Content Management System) Wordpress dan digunakan dalam proses pembelajaran IPA secara online ini telah berhasil dilaksanakan (Januarisman \& Ghufron, 2016).

Sebagaimana pada penelitian pengembangan terdahulu dengan judul Pengembangan E-Modul Berbasis Project Based Learning Pada Mata Pelajaran Simulasi Digital Untuk Siswa Kelas X Studi Kasus Di SMK Negeri 2 Singaraja dengan hasil bahwa e-modul berbasis project based learning pada mata pelajaran simulasi digital rata-rata didapat persentase berdasarkan hasil pengujian yang dilakukan, Secara umum siswa terlihat antusias dan terlibat aktif selama proses pembelajaran berlangsung. Rata-rata persentase keseluruhan subyek sebesar 90,6\%. Jika dikonversikan kedalam tabel konversi termasuk dalam kategori sangat baik (Wijayanti, Damayanthi, Sunarya, \& Putrama, 2016). 
Menanggapi hal itu, seiring perkembangan teknologi informasi (IT), berbagai inovasi teknologi telah dikembangkan. Kehadiran teknologi informasi (IT) dalam dunia pendidikanpun juga sangat penting, kebutuhan akan suatu konsep dan mekanisme belajar mengajar berbasis teknologi informasi (IT) menjadi hal utama dalam peningkatan pembelajaran. Teknologi ini dikenal dengan istilah e-learning.

E-Learning merupakan metode pembelajaran yang memanfaatkan teknologi informasi (IT) berbasis web yang dapat di akses dari jarak jauh sehingga pembelajaran yang dilakukan tidak hanya terpaku dalam ruang kelas dan dalam jam tertentu saja. Namun dapat tetap dilakukan kapan saja dan dimana saja sehingga metode pembelajaran ini dinilai lebih efektif dan efisien untuk diterapkan (Yunitasari \& Hanifah, 2020) .

Pembelajaran berbasis web merupakan salah satu contoh dari pembelajaran Elektronik (E-Learning) dengan menggunakan teknologi internet sebagai sarana belajar. (Batubara, 2018). Oleh sebab itu Inovasi dalam pembelajaran e-learning merupakan model pembelajaran baru dalam pendidikan dimana memberikan peran dan fungsi yang besar bagi dunia pendidikan (Puspitarini \& Hanif, 2019). Hal ini untuk menjawab kekurangan dan kelemahan pendidikan konvensional (pendidikan pada umumnya) diantaranya adalah keterbatasan ruang dan waktu dalam proses pendidikan konvensional.

SMKN 2 SITUBONDO telah menerapkan pembelajaran daring dengan berbasis website. Maka dengan fenomena diatas, peneliti mengangkat judul Analisis Efektifitas Pembelajaran Daring berbasis website Studi Kasus Siswa Kelas X Akuntasi 1 di SMKN 2 SITUBONDO Mata Pelajaran SIMDIG.

\section{METODE}

Lokasi penelitian ini bertempat di Sekolah Menengah Kejuruan Negeri 2 Situbondo yang bertempat di desa talkandang kecamatan situbondo kabupaten situbondo dan penelitian ini dilakukan pada tahun ajaran 2020-2021 semester ganjil.

Pendekatan penelitian yang digunakan dalam penelitian adalah kualitatif deskriptif karena dalam penelitian ini menghasilkan kesimpulan berupa data yang menggambarkan secara rinci, bukan data yang berupa angka-angka.Hal ini karena 
pendekatan kualitatif sebagai prosedur penelitian yang menghasilkan data deskriptif berupa kata-kata tertulis atau lisan dari orang-orang dan perilaku yang diamati.Penelitian kualitatif adalah suatu pendekatan ilmiah yang mengungkap situasi sosial tertentu dengan mendeskripsikan kenyataan secara benar, dibentuk oleh katakata berdasarkan teknik pengumpulan analisis data yang relevan yang diperoleh dari situasi yang alamiah.

Dengan teknik pengamatan,wawancara, dan dokumentasi pada obyek penelitian sehingga dihasilkan data yang menggambarkan secara rinci.Penelitian ini adalah deskriptif, karena tujuan dari penelitian deskriptif yaitu untuk membuat deskripsi, gambaran atau lukisan secara sistematis, faktual dan akurat mengenai fakta-fakta, sifatsifat serta hubungan antar fenomena yang diselidiki. Sesuai dengan fokus dan tujuan penelitian, jenis penelitian ini sangat tepat karena peneliti akan mendeskripsikan data bukan untuk mengukur data yang diperoleh. Adapun jenis penelitian yang digunakan dalam penelitian ini adalah penelitian kualitatif studi kasus yang bertujuan untuk mempelajari latar belakang, keadaan dan interaksi yag terjadi.

Sebagaimana yang dikemukakan Miles dan Hubberman (Sugiyono, 2017) yaitu pengumpulan data, reduksi data, penyajian data dan langkah terakhir adalah penarikan kesimpulan. Langkah-langkah yang pertama yaitu reduksi data merupakan penyerderhanaan yang dilakukan melalui seleksi, pemfokusan dan keabsahan data mentah menjadi informasi yang bermakna, sehingga memudahkan penarikan kesimpulan. Kedua, Penyajian data yang sering digunakan pada data kualitatif adalah bentuk naratif.Penyajian-penyajian data berupa sekumpulan informasi yang tersusun secara sistematis dan mudah dipahami. Dan yang ketiga Penarikan kesimpulan merupakan tahap akhir dalam analisis data yang dilakukan melihat hasil reduksi data tetap mengacu pada rumusan masalah secara tujuan yang hendak dicapai. Data yang telah disusun dibandingkan antara satu dengan yang lain untuk ditarik kesimpulan sebagai jawaban dari permasalahan yang ada. Dengan uji keabsahan temuan menggunakan teknik Trianggulasi data. Menurut Moloeng (Moleong, 330: 2007) Triangulasi adalah teknik pemeriksaan keabsahan data yang memanfaatkan sesuatu yang lain diluar data untuk keperluan pengecekan atau sebagai pembanding terhadap 
data itu sendiri.

\section{HASIL DAN PEMBAHASAN}

Peneliti melakukan wawancara terhadap siswa kelas X AKL 1 Sekolah Menengah Kejuruan Negeri 2 Situbondo. Sebagaimana dijelaskan dalam BAB ketiga, peneliti menggunakan metode wawancara tidak terstruktur dan pertanyaan terbuka. Artinya pedoman wawancara yang digunakan hanya berupa garis-garis besar permasalahan yang akan ditanyakan. Sedangkan pemilihan bentuk pertanyaan terbuka ini dimaksudkan supaya memberikan keleluasaan bagi responden untuk memberikan jawaban dengan bebas tanpa dibatasi oleh alternatif jawab yang ditentukan. efektifitas pembelajaran daring berbasis website.

\section{PEMBAHASAN}

Pendekatan kualitatif merupakan prosedur penelitian yang menghasilkan data deskriptif berupa kata-kata tertulis atau lisan dari orang-orang dan perilaku yang dapat diamati. Penelitian dengan metode kualitatif berusaha memahami dan menafsirkan makna suatu peristiwa interaksi tingkah laku manusia dalam situasi tertentu menurut perspektif peneliti sendiri. Penelitian yang menggunakan penelitian kualitatif bertujuan untuk memahami obyek yang diteliti secara mendalam (imam gunawan, 2013).

Dari hasil wawancara terhadap siswa kelas X AKL 1 yang menjadi responden,terdapat beberapa jawaban yang berbeda-beda. Hal ini disebabkan karena sudut pandang setiap orang pasti tidak sama dalam menyikapi sebuah permasalahan.

Dina, salah seorang siswi menjawab "Untuk memahami sebuah materi itu kembali pada pribadi masing-masing siswa. bagi saya sendiri, meskipun guru tidak menjelaskan secara langsung, tetapi siswa bisa mencari alternatif lain untuk memahami materi yang diberikan oleh guru, salah satunya yang saya pakai adalah dengan menanyakan langsung hal yang kurang saya pahami dari materi yang diberikan kepada guru melalui pesan di WhatsApp" jawab Dina.

Dari jawaban diatas bisa kita artikan bahwa untuk memahami suatu pembelajaran itu tergantung kepada pribadi masing-masing siswa. Meskipun tidak bertatap muka dengan guru, itu tidak bisa diajadikan sebuah alasan untuk siswa tidak bisa memahami materi yang diberikan. Karena, banyak alternatif lain yang bisa siswa gunakan untuk 
membuat dirinya memahami sebuah materi. Salah satunya siswa bisa menanyakan apa yang tidak di mengerti kepada guru melalui pesan di WhatsApp.

Sementara itu beberapa siswa juga memberikan cara supaya dirinya bisa memahami materi yang diberikan oleh guru yaitu dengan cara mencari referensi tambahan dari berbagai sumber guna menambah pemahaman dari materi yang dijelaskan. Ivan, salah satu responden mengatakan bahwa saya berusaha mencari referensi tambahan dari sumber lain guna menambah pemahaman dari materi yang diberikan oleh guru" .

Sebagaimana dituliskan oleh (Firman \& Sari., 2020) dalam penelitian terdahulu menyatakan bahwa pembelajaran online lebih mengarah pada student centered sehingga mampu memunculkan tanggung jawab dan otonomi mahasiswa dalam belajar. Sehingga membuat siswa lebih mampu menumbuhkan kemandirian dalam belajar.

Saat ditanya tentang kelebihan pembelajaran online dengan menggunakan media website, secara garis besar siswa memberikan jawaban hampir sama yaitu Mudah dalam mengakses website dan tidak membuat penyimpanan cepat habis. Terkait dengan kelebihan pembelajaran online banyak dari siswa yang mengatakan bahwa pembelajaran online sangat fleksibel, tidak membutuhkan waktu yang lama dan memberikan pengalaman baru bagi siswa.

"Kelebihan pembelajaran online menurut saya sangat fleksibel dan praktis artinya kita tidak usah jauh-jauh menempuh jarak untuk bertemu dengan guru. Kita cukup berinteraksi dengan guru melalui media yang dipakai dalam pembelajaran online. selain itu, pembelajaran juga bisa dilakukan di mana saja dan kapan saja" jawaban dari Amanda.

Salah satu responden yang bernama Mila mengatakan bahwa pembelajaran online memberikan pengalaman belajar yang lebih menyenangkan. Sebelumnya saya belajar dengan metode tatap muka yang itu identik dengan spidol dan papan tulis. Namun, sekarang materi yang disajikan lebih bervariasi dengan berupa foto, video dan audio. Hal ini menjadi pengalaman tersendiri bagi Mila. 
Dimas, salah seorang siswa juga mengatakan bahwa dirinya Saat ini dirinya mempunyai banyak waktu yang bisa digunakan untuk membantu orang tua dirumah. "Kita bisa menghemat waktu. Karena, dalam prosesnya, pembelajaran online tidak memakan waktu yang lama. Sehingga saya mempunyai banyak waktu yang bisa digunakan untuk membantu orang tua dirumah".

Terkait dengan kemudahan yang didapatkan melalui pembelajaran online berbasis website siswa mengatakan bahwa media website itu mudah diakses melalui HP apa saja. meskipun HP tersebut mempunyai ram dan penyimpanan yang tidak banyak. Sehingga tidak membuat HP menjadi lemot.

Mayoritas siswa juga mengatakan bahwa pembelajaran online tidak membuat mereka bosan. Bagi mereka pembelajaran online merupakan pengalaman baru khususnya di dunia pendidikan. selain itu, dalam prosesnya pembelajaran online tidak membutuhkan waktu yang lama sehingga siswa mempunyai banyak waktu kosong dirumahnya. Tidak hanya itu Pembelajaran online tidak terikat seperti di dalam kelas artinya siswa dalam mengikuti pelajaran bisa dilakukan dengan santai.

Meskipun banyak kemudahan dalam pembelajaran online bukan berarti dalam pembelajaran online tidak memiliki kendala. Dari wawancara yang dilakukan sebagian narasumber mengatakan bahwa masalah utama dari pembelajaran online yaitu terletak pada sinyal HP yang terkadang tidak stabil, hal ini dialami bagi siswa yang rumahnya terletak di pelosok desa. Namun terkait ini, siswa mengatakan bahwa hal ini bukanlah suatu permasalahan yang serius karena siswa bisa pindah terlebih dahulu ke tempat yang cakupan sinyalnya cukup baik.

Mayoritas responden juga berpendapat bahwa pembelajaran online sangat efektif dan efisien untuk saat ini mengingat kondisi sekarang yang sedang dilanda wabah covid-19. Kemendikbud menganjurkan bahwa pembelajaran harus dilakukan dengan jarak jauh. Pembelajaran online berbasis website merupakan salah satu metode pembelajaran yang diterapkan guna memenuhi kebutuhan pembelajaran di sekolah.

Siswa mengatakan efisien dan dan efektif karena dalam pelaksanaan pembelajarannya siswa merasa lebih rileks dan santai dibandingkan pada saat pembelajaran di sekolah. Selain itu pembelajaran online dinilai sangat singkat artinya 
tidak membutuhkan waktu yang lama seperti pembelajaran tatap muka di sekolah (A.N, Bayu, Rani, \& Meidawati, 2019).

Namun dalam kendala pembelajaran daring melalui E-learning adalah jika jaringan nya terputus dan aktifitas jaringan sibuk. Sehingga memungkinkan siswa harus menunggu waktu untuk mengupload tugas yang telah dikerjakan. Salah satunya adalah ketersediaan jaringan internet. Beberapa mengaku kesulitan untuk mengikuti pembelajaran online karena tidak semua wilayah mendapatkan jaringan internet dengan akses lancar (Hasanah dkk, 2020).

Setelah mengetahui jawaban-jawaban mengenai pembelajaran jarak jauh menggunakan basis Web, dapat disimpulkan bahwa teknologi memiliki peran penting dalam pelaksanaan Kegiatan Belajar Mengajar (KBM) agar tetap berjalan efektif. Penggunaan media pembelajaran membantu guru dan siswa untuk tetap saling terhubung selama pemberian materi atau tugas serta pengumpulan tugas. Teknologi dapat memberikan dampak baik pada musim pembelajaran Daring: pertama, terciptanya berbagai platform pembelajaran. Hal ini memberikan kemudahan bagi guru dan peserta didik dalam menjalani proses pembelajaran jarak jauh. Hadirnya platform yang dapat digunakan memberikan pengetahuan dan pengalaman baru pada peserta didik mengenai perkembangan teknologi. Baik aplikasi, web/blog, video, podcast ataupun yang lainnya. Adanya platform belajar seperti ruang guru, zenius, dll dapat menjadi jembatan peserta didik dalam belajar. Memudahkan mereka dalam memahami pembelajaran yang dilakukan dengan tidak tatap muka. Kedua, teknologi pendidikan memudahkan peserta didik dalam mencari sumber belajar. Melihat dari media pembelajaran yang digunakan saat pandemi ini, peserta didik lebih leluasa dalam mencari sumber belajar. Menggunakan jaringan internet dan media yang telah tersedia, peserta didik dapat mengakses sumber belajar yang mereka butuhkan. Namun, apabila penggunaan internet tidak digunakan dengan baik, kemungkinan terburuk ialah peserta didik dapat mengakses hal-hal yang tidak dibutuhkan ataupun merusak moral. Ketiga, memberi kemudahan bagi guru dalam menyampaikan materi pembelajaran kepada peserta. Dengan adanya teknologi pendidikan, pembelajaran lebih lues dilakukan tanpa 
harus bertatap muka (Hasnifah Salsabila, Irna Sari, Haibati Lathif, Puji Lestari, \& Ayuning, 2020)

\section{SIMPULAN}

Peneliti memperoleh kesimpulan bahwa pembelajaran online Berbasis website efektif bagi siswa dengan alasan : Siswa tetap dapat memahami materi dengan mudah di akses. Pembelajaran online berbasis website tidak membutuhkan waktu yang lama sehingga siswa mempunyai banyak waktu luang yang bisa digunakan untuk membantu orang tua di rumah.

\section{DAFTAR RUJUKAN}

A.N, S., Bayu, Rani, \& Meidawati. (2019). PERSEPSI SISWA DALAM STUDI PENGARUH DARING LEARNING TERHADAP MINAT BELAJAR IPA Universitas Veteran Bangun Nusantara Sukoharjo Email : nugrahaadi7650@gmail.comm. Jurnal Pendidikan Islam Dan Multikulturalisme, $1(2), 30-38$.

Firman \& Sari. (2020). Pembelajaran Online di Tengah Pandemi Covid-19. ,. Indonesian Journal Of Educational Science (IJES), 02 No 02.hamdan husein batubara. (2018). Pembelajaran berbasis Web dengan Moodle versi 3.4.

Hanifah Salsabila, U., Irna Sari, L., Haibati Lathif, K., Puji Lestari, A., \& Ayuning, A. (2020). Peran Teknologi Dalam Pembelajaran Di Masa Pandemi Covid-19. Al-Mutharahah: Jurnal Penelitian Dan Kajian Sosial Keagamaan, 17(2), 188198. https://doi.org/10.46781/al-mutharahah.v17i2.138

Imam Gunawan. (2013). metode penelitian kualitatif. learning university.

Januarisman, E., \& Ghufron, A. (2016). Pengembangan Media Pembelajaran Berbasis Web Mata Pelajaran Ilmu Pengetahuan Alam Untuk Siswa Kelas Vii. Jurnal Inovasi Teknologi Pendidikan, 3(2), 166.

https://doi.org/10.21831/jitp.v3i2.8019

Moleong, L. J. (2007). Metodologi Penelitian Kualitatif. PT Remaja Rosdakarya. Puspitarini, Y. D., \& Hanif, M. (2019). Using Learning Media to Increase Learning Motivation in Elementary School. Anatolian Journal of Education, 4(2), 53-60. https://doi.org/10.29333/aje.2019.426a 
Sugiyono. (2017). Metode Penelitian Kuantitatif, Kualitatif dan R\&D. bandung: alfabeta.

Wijayanti, N. P. A., Damayanthi, L. P. E., Sunarya, I. M. G., \& Putrama, I. M. (2016). Pengembangan E-Modul Berbasis Project Based Learning Pada Mata Pelajaran Simulasi Digital Untuk Siswa Kelas X Studi Kasus Di Smk Negeri 2 Singaraja. Jurnal Pendidikan Teknologi Dan Kejuruan, 13(2), 184-197. https://doi.org/10.23887/jptk-undiksha.v13i2.8526

Yunitasari, R., \& Hanifah, U. (2020). Pengaruh Pembelajaran Daring terhadap Minat Belajar Siswa pada Masa COVID 19. Edukatif : Jurnal Ilmu Pendidikan, 2(3), 232-243. https://doi.org/10.31004/edukatif.v2i3.142 